\title{
Shelf List As Union Catalog
}

\author{
By DONALD CONEY AND GEORGE PITERNICK
}

$I^{N}$ N ATTEMPTING TO ARRIVE at a reasonable plan of development the libraries of the seven University of California campuses have been exploring for some time means of providing the best possible intercampus access to their library collections. Since it appears certain that the student populations of the campuses will expand very rapidly, with corresponding increases of teachers, faculty interest in improved means of intercampus access is high.

One of the access devices frequently mentioned in faculty discussions is the well known union card catalog. This bibliographical device appears to have entrenched itself in the layman's concept of vital library apparatus. The union catalog, however, received its greatest development during the Depression as a byproduct of massive white collar relief projects. Of the many union card catalogs launched during the thirties with W.P.A. and other governmental aid, only a relatively few are alive today, and most of these are sadly in arrears. It is doubtful that any conceivable increase in the intercampus use of library materials would justify the cost of a catalog of this type at each campus. There is another means, however, by which the intercampus availability of books can be advertised, at far lower cost. This is the printed catalog.

To obtain union catalog coverage it is not essential that the holdings listings of the member libraries be interfiled into a single catalog, desirable though that may be. Basically, a group of separate printed catalogs, each containing the holdings of one of the campus libraries, constitutes a union catalog. Need all the campuses be represented by their catalogs? Fully 85 per cent of the books held by University
Mr. Coney is Librarian, and Mr. Piternick, Library Administrative Analyst, University of California, Berkeley.

of California libraries are located either in Berkeley or Los Angeles, and it appears likely that catalogs of these two collections, available on all campuses, would take care of the great majority of all intercampus interlibrary transactions. (In 1959/60, 87 per cent of all intercampus interlibrary loans within the University of California were made from the Berkeley and Los Angeles campuses.)

The arrangement of such printed catalogs offers a variety of possibilities:

Author (main entry). Although this arrangement is the most usual and obvious, it offers perhaps the least additional benefit to what facilities already exist in the way of intercampus lending aids. It is not difficult at present, through the services of the National Union Catalog and the communication facilities now existing (which include Teletype), to locate a book in one of the University of California libraries if a specific title is wanted. A printed author catalog would perhaps facilitate the process somewhat, but it would be of no practical aid in cases where information on a given subject area were the desideratum. It is felt that this need for subject aid is the major one facing faculty and research personnel on the smaller campuses.

Subject. Arrangement by subject in a printed catalog has many obvious advantages. Its disadvantages lie in its relatively greater bulk, and in the alphabetical arrangement of fairly specific subject headings which has the effect of obscuring hierarchical subject relationships.

Shelf list. A shelf list catalog of a li- 
brary's holdings has one characteristic which would make it extremely useful in meeting the needs envisaged. A printed shelf list catalog is the closest possible equivalent to visiting the library represented and examining the books on its shelves. It is felt that this approach is the one most desired by the research personnel on the several campuses.

The idea of using a series of separately printed shelf lists in book form appears to be sufficiently unusual to provoke initial rejection. To the observation that classified arrangement makes such a list difficult to use can be opposed the fact that a public shelf list has been used successfully for many decades by students and faculty at the Berkeley campus of the University of California as a valued supplement to the author-title and subject catalogs. The users of this shelf list, employing the $\mathrm{Li}$ brary of Congress classification schedules as a key, apparently become accustomed to going to a particular location in the shelf list in much the same way as they learn to go to a particular location in the stacks for materials in their fields of interest. There are two interesting advan- tages to the use of the shelf list for this purpose which merit careful consideration. One, mentioned earlier, is that the shelf list is the least bulky of the several card records which can be duplicated in book form and, hence, the least expensive to manufacture. The other is that publication of a shelf list could proceed serially, each part being useful as published to a much higher degree than a segment of an alphabetically arranged list. This same advantage would permit the omission of some sections of the shelf list whose use might be judged to be insufficient to justify publication. To the objection that the shelf list may offer a less complete subject presentation of the library's holdings than the subject catalog, answer can be made that in relation to cost it may be quite enough, and that the subject catalog itself falls short of utter perfection.

This approach to a substitute for a conventional union catalog will receive further study at the University of California. The authors of this article would be interested in having comments on the ideas put forward.

\section{Reason Named Rangoon Library Adviser}

Joseph H. Reason, director of libraries at Howard University, Washington, D. C., has been appointed library adviser to the library of the Social Sciences Faculty of the University of Rangoon, Rangoon, Burma. He will be on leave from Howard for two years. Norman D. Stevens will serve as acting director of libraries there during Mr. Reason's absence.

Mr. Reason left for Burma at the end of April. His wife will join him there later in the summer. In his position as library adviser at the University of Rangoon he succeeds Paul Bixler, head librarian of Antioch College, Yellow Springs, Ohio. The library of the Social Sciences Faculty of the University of Rangoon is a project supported by funds made available by the Ford Foundation and administered by ALA through a committee of ACRL. Robert B. Downs, dean of library administration at the University of Illinois, is chairman of this committee. 